doi: 10.32620/oikit.2021.91.04

УДК 621.78

\author{
Е.А. Фролов ${ }^{1}$, С.В. Попов ${ }^{2}$, \\ С.Г.Ясько ${ }^{3}$, О.В. Орисенко ${ }^{1}$
}

\title{
Детонаційно-газове зміцнення деталей двигунів внутрішнього згорання
}

\author{
${ }^{1}$ Національний університет «Полтавська політехніка імені Юрія Кондратюка» \\ ${ }^{2}$ Полтавський державний аграрний університет \\ ${ }^{3}$ Державний вищій навчальний заклад «Приазовський державний технічний \\ університет»
}

Робота присвячена підвищенню надійності та довговічності деталей циліндропоршневої групи двигунів внутрішнього згорання. Зміцнення деталей машин можливе за рахунок застосування спеціальних технологічних процесів. Сучасні матеріали та покриття повинні задовольняти високим робочим температурам і навантаженням. Хромування, борування та іонно-плазмове напилення не задовольняють встановленим вимогам якості. Алюмінієвий поршень зазнає руйнувань в районі головки. Це проявляється у накопиченні шпарин, каналів, слідів вимивання сплаву. Окрім цього, внаслідок нагрівання, втрачається міцність алюмінієвого сплаву більше, ніж у 2 рази. Запропоновано створення та застосування покриття, яке б витримувало робочі температури понад $2000^{\circ} \mathrm{C}$, а також ударно-пульсуючі навантаження. Пропонується детонаційно-газовий метод напилення. Він характеризується універсальністю матеріалів: від полімерів до тугоплавкої кераміки, любі метали і сплави. Напилені частинки володіють високою кінетичною енергією. Покриття характеризується високою міцністю, яка сягає 180...200 МПа, твердістю HRCe 60, мінімальною шпаринністю. Температурний вплив при напиленні на заготовку незначний. Запропоновано послідовність підготовчих операцій. Зміцненню підлягали поршень та жарове кільце на детонаційно-газовій установці «УН-102». Застосовувався маніпулятор, що використовує енергію пострілу установки. Отримані поверхні характеризуються регулярною макроструктурою (хвилястістю). Нанесенню підлягав нікель-алюмінієвий сплав. Товщиною покриття - 150...270 мкм, твердість - HV 550, адгезія до основи 94...100 МПа. Результати досліджень на деталях циліндро-поршневої групи засвідчили зниження робочих температур, внаслідок припрацьовування покриття та якісного ущільнення камери згорання. Довговічність кілець становить $1,6 \cdot 10^{6} \ldots 2,3 \cdot 10^{6}$, що свідчить про значне підвищення опору втомі та ресурсу роботи. Запропонована технологія є придатною та рекомендується до впровадження у серійне виробництво.

Ключові слова: детонаційно-імпульсне зміцнення, поршень, жарове кільце, напилення, покриття.

\section{Вступ}

Надійність та довговічність роботи деталей циліндро-поршневої групи двигунів внутрішнього згорання суттєво впливає на життєвий цикл самого двигуна. Перспективним напрямком підвищення стійкості та довговічності цієї групи деталей $є$ нанесення на їх робочі поверхні зміцнювальних покриттів.

У сучасному машинобудуванні особливе місце займають технології, що пов'язані 3 наданням робочим поверхням деталей машин необхідних властивостей, що забезпечують підвищення їх експлуатаційних характеристик [1-3].

Задача подальшого фрорсування двигунів внутрішнього згорання пов'язана перед усім із необхідністю покращення фрізико-технічних властивостей деталей циліндро-поршневої групи за рахунок застосування нових жароміцних матеріалів та сучасних покриттів, що задовольняють температурі та 
навантаженням в конструкціях двигунів внутрішнього згорання.

Існуючі технології створення захисних покриттів (хромування, борування, іонно-плазмове напилення) не задовольняють встановлені вимоги до деталей двигунів внутрішнього згорання, що працюють при високих температурах та значних навантаженнях [4-5].

Поршень, виготовлений з алюмінієвого сплаву АК4-1 із заштампованим кільцетримачем та камерою згорання із жароміцної сталі під час роботи зазнавав впливу продуктів згорання із максимальною температурою $2000^{\circ} \mathrm{C}$ та пульсуючим тиском 0,1..10 МПа. Під час роботи в умовах багатопаливності відбувається руйнування головки поршня (торцева і бічна поверхні) та кромок камери згорання. При огляді (після випробувань обкатки обсягом 500 годин) встановлено, що пошкоджені ділянки являють собою накопичення шпарин та каналів зі згладженими стінками та слідами вимивання сплаву. Таким чином, можливо припустити, що руйнування відбувалося за кавітаційно-ерозійним механізмом [4].

Окрім того, в результаті нагріву головки поршня до температури $450^{\circ} \mathrm{C}$ відбувається втрата міцності алюмінієвого сплаву - твердість після випробування, виміряна поблизу поверхні головки, склала НВ $52 \ldots 56$ порівняно із початковою НВ 121...126 [4].

Таким чином, захист поверхонь поршня, які зазнають пошкоджень від впливу високотемпературного газового потоку є вкрай актуальною задачею.

Метою роботи було створення та застосування вже відомого покриття, яке б витримувало під час роботи температури понад $2000^{\circ} \mathrm{C}$, а також діючий на нього ударний пульсуючий тиск.

\section{Основний матеріал}

Як засвідчили порівняльні випробування найбільш прийнятною $є$ технологія і обладнання, що здійснює детонаційно-газове зміцнення.

Детонаційно-газовий метод напилення дозволяє не лише відновлювати робочі поверхні виробів та деталей, але й суттєво підвищити їх експлуатаційний ресурс. Для нанесення покриттів цим способом можуть бути використані практично любі матеріали: від полімерів до тугоплавкої кераміки, а також любі метали і сплави. Розмір частинок порошку, що застосовується для нанесення покриттів, зазвичай знаходиться у межах 5...100 мкм залежно від матеріалу порошку та потрібних параметрів шпаринності покриттів. Частинки, що напиляються, володіють надзвичайно високою кінетичною енергією. Це визначає рівень міцності покриттів. Він на порядок перевищує міцність зчеплення покриттів, що отримані іншими газотермічними та газоелектричними способами. Міцність покриттів може сягати 180..200 МПа, залежно від матеріалу покриття та деталі. До того ж детонаційно-газові покриття мають мінімальну шпаринність - до 0,5...1,0\% (газополуменеві - 10\%, а плазмові $2 \%)$. При цьому, як правило, при фрормуванні покриття температура деталі при напиленні залежить від її розмірів, не перевищує 530 К, що відповідає низькому відпалу. Внаслідок малої тривалості процесу напилення, температурний вплив незначний. Відсутня деформація деталі, що напилюється.

До особливостей даного способу також слід віднести:

- можливість плавного та стійкого регулювання параметрів процесу в широких діапазонах. Це дозволяє для кожного матеріалу встановити найбільш оптимальні режими напилення; 
- застосування дрібнодисперсних композиційних матеріалів для напилення дозволяє фрормувати покриття із шорсткістю від 10 до 20 мкм, що в деяких випадках не вимагає додаткової механічної обробки;

- висока енергія продуктів детонації, що прискорює частинки, і підвищує їх температуру дозволяє формувати покриття із тугоплавких матеріалів не лише на металевих деталях із твердістю поверхні $\mathrm{HRC}_{\mathrm{e}} 60$ та вище, але й на неметалевих матеріалах (скло, кераміка, дерево, картон та ін.).

Перед напиленням необхідно забезпечити виконання наступних підготовчих операцій:

- деталі повинні бути остаточно механічно оброблені окрім місць, що підлягають зміцненню. В цих місцях повинен бути видалений шар металу, що дорівнює товщині зміцнювального покриття;

- підготовка поверхні, зберігання і транспортування підготовлених під зміцнення відбувається у приміщенні при температурі не нижче $18^{\circ} \mathrm{C}$ та відносній вологості не вище 75\%. При цьому не допускається наявність у навколишньому середовищі речовин, що сприяють корозії поверхонь, що зміцнюються;

- поверхні зміцнення підлягають струйно-абразивній обробці в спеціальній камері під тиском стисненого повітря 0,4...0,6 МПа, відстань від зрізу сопла повітряного пістолета до оброблюваної поверхні $40 . .70$ мм, кут нахилу потоку $60 . . .90^{\circ}$;

- поверхні, що не підлягають зміцненню, захищаються від впливу струйноабразивної обробки, а також подальшого напилення, спеціальними екранами;

- після струйно-абразивної обробки відбувається обдування стисненим повітрям для видалення частинок абразиву;

- якість підготовки поверхні деталі під зміцнення контролюється зовнішнім оглядом із застосуванням лупи 4-кратного збільшення. Шорсткість поверхні повинна бути Rz 80...100 за ГОСТ 2789.

Було зміцнено дослідну партію деталей двигунів внутрішнього згорання поршень та жарове кільце. Напилення виконано на детонаційно-газовій установці «УН-102», до складу якої входить маніпулятор, що забезпечує синхронне переміщення деталі під час фрормування покриття. Загальний вигляд установки для детонаційно-газового зміцнення «УН-102» представлено на рис. 1, а технічна характеристика в табл. 1.

Жарове кільце являє собою кільце манжетного типу L-подібного перерізу. Одним своїм елементом - манжетою, контактуюче із циліндром, а другим полкою - із поршнем. Таким чином здійснюється ущільнення камери згорання.

Під час роботи жарове кільце зазнає термічних та механічних навантажень. Температура жарового кільця становить від $300^{\circ} \mathrm{C}$ на манжеті до $420^{\circ} \mathrm{C}$ на полці. Руйнування кілець в експлуатації починається завжди з манжети та має втомний характер.

Дослідні поршні виконані без застосування жароміцної сталі для камери згорання, тобто контур камери було виконано повністю з алюмінієвого сплаву, а гострі кромки камери згорання мають заниження до центра [6].

Детонаційно-газовому напиленню було піддано зовнішню поверхню манжети жарового кільця. Напилення виконувалось із застосуванням оригінального маніпулятора, що використовує енергію пострілу детонаційногазової установки.

Застосування даного маніпулятора дозволило отримати на поверхні 
жарового кільця покриття із суворо регулярною макроструктурою (хвилястістю).

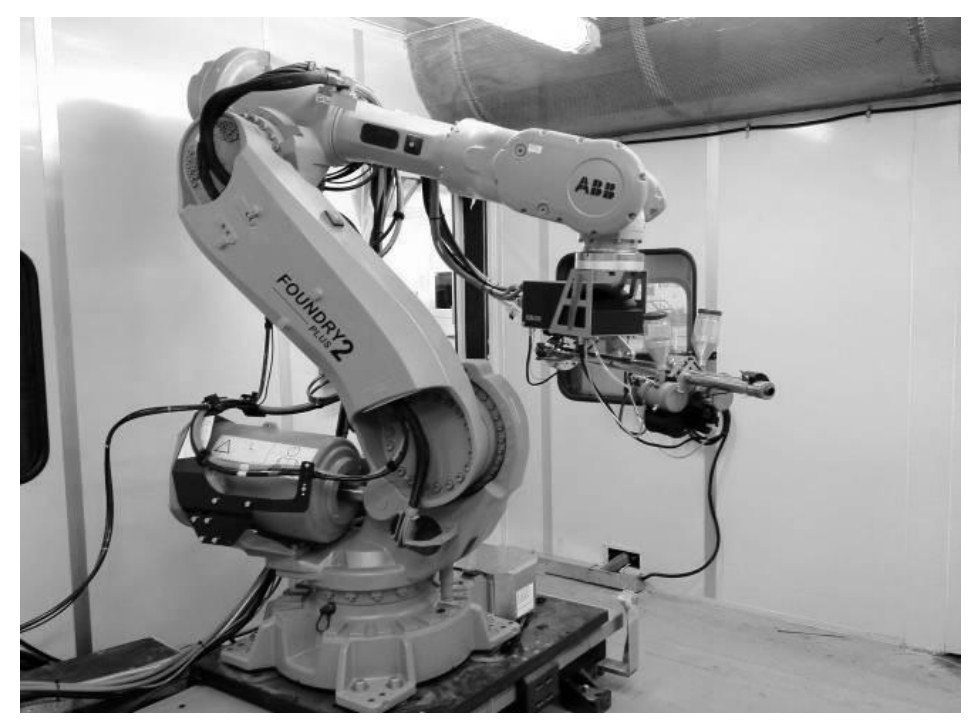

Рис. 1. Установка детонаційно-газового зміцнення «УН-102», встановлена на промисловому маніпуляторі

Технічна характеристика установки «УН-102»

\begin{tabular}{|c|c|}
\hline Параметр & Значення \\
\hline Калібр ствола, мм & 20 \\
\hline Довжина ствола, мм & $640 \ldots 1840$ \\
\hline Швидкострільність, цикл/с & до 15 \\
\hline Подача порошку до ствола & радіальна \\
\hline Об'єм бункера дозатора, мл & 160 \\
\hline Товщина покриття за 1 постріл, мкм & $2 \ldots 20$ \\
\hline Коефріцієнт використання порошку & до 0,8 \\
\hline Робочі гази & $\begin{array}{c}\text { газоподібне паливо } \\
\text { (ацетилен, пропан, водень), } \\
\text { кисень, азот (повітря) }\end{array}$ \\
\hline Робочий тиск усіх газів, МПа & $0,12 \pm 0,01$ \\
\hline $\begin{array}{l}\text { Співвідношення палива та кисню у горючій } \\
\text { суміші }\end{array}$ & від 1:1 до 1:5 \\
\hline $\begin{array}{l}\text { Швидкодія: газових клапанів, порошкових } \\
\text { дозаторів, мс }\end{array}$ & $12^{+2} ; 16^{+2}$ \\
\hline Система охолодження & водяна, замкнена \\
\hline Керування & $\begin{array}{l}\text { дистанційне, автоматичне, } \\
\text { програмоване }\end{array}$ \\
\hline Напруга живлення, В & $380 / 220$ \\
\hline Найбільша споживана потужність, кВт & 5 \\
\hline Габаритні розміри, мм & $2500 \times 644 \times 1200$ \\
\hline Maca, кг & 360 \\
\hline
\end{tabular}

Матеріал покриття - нікель-алюмінієвий сплав із товщиною покриття 150...270 мкм, твердістю - HV 550, адгезією до основи - 94...100 МПа. Після покриття кільце шліфувалося. 
Це стало можливим завдяки високій точності ( $\pm 0,05$ мм) відтворення кроків напилення (інтервалів між одиничними плямами), розрахованими виходячи з форми плями напилення, що забезпечило формування шару покриття із мінімальним рівнем залишкових напружень i, що особливо важливо, суворо однаковим за усією довжиною кола жарового кільця.

Порівняльні випробування щодо визначення температурного стану та втомної міцності жарового кільця, що здійснювались на підприємствівиробникові двигунів внутрішнього згорання (Державне підприємство «Завод імені В.О. Малишева, м. Харків»), засвідчили наступне:

- на кільцях із зміцнювальним покриттям досягнуто (на $45^{\circ} \mathrm{C}$ на манжеті та $110^{\circ} \mathrm{C}$ на полці) зниження температури нагріву. Це зумовлено добрим припрацюванням покриття та, як наслідок, якісним ущільненням камери згорання;

- кільця із ущільнювальним покриттям, випробувані циклічним навантаженням (змінюється за знакопостійним циклом), мали довговічність $1,6 \cdot 10^{6} ; 1,83 \cdot 10^{6}$ та 2,3 $10^{6}$ циклів - для серійних кілець.

Отже, можливо стверджувати про значне підвищення опору втомі жарових кілець, зміцнених детонаційно-газовим методом. Як наслідок, маємо підвищення ресурсу.

\section{Висновки}

Отримані напилені покриття із високими якісними показниками. На основі поведених досліджень можна зробити висновок про те, що нанесення зносостійких та міцних покриттів детонаційно-газовим напиленням на деталі циліндро-поршневої групи дозволить забезпечити економію металу та зменшити витрати на заміну даних деталей.

Тривалі стендові та натурні випробування дослідної партії поршнів із детонаційно-газовим зміцненням, проведені за повною програмою підприємства-виробника двигунів внутрішнього згорання, показали повну придатність розробленої технології зміцнення для різкого підвищення працездатності двигуна. Дана технологія може бути впроваджена у серійне виробництво.

\section{Список літератури}

1. Буденный М.М. Повышение ресурса и надежности деталей машин методом детонационно-газового напыления упрочняющих покрытий / М.М.Буденный, В.И.Власенко, А.Я.Мовшович // Вестник национального технического университета «ХПИ»: Сборник научных трудов. - Харьков: НТУ «ХПИ», 2001. - №11. - C. 94-98.

2. Popov S. Improving the abrasive resistance of a slide frame in a mortar mixer / S. Popov, S. Gnitko, A. Vasyliev // Eastern-European Journal of Enterprise Technologies. - 2020. - №1/1(103). - P. 6-14.

3. Попов С.В. Визначення характеристики газополуменевого напилення на основі багатофакторного експерименту / С.В. Попов // Машинознавство. 2008. - №10. - C.45-47.

4. Этингант А.А. Особенности вакуумно-плазменного упрочнения режущего инструмента из быстрорежущей стали / А.А. Этингант, В.С. Стороженко, А.В. Колядинский // Передовой опыт. - Киев, 1986. - № 12. - С. 27-30. 
5. Богуслаев А.В. Исследование качества материала деталей после нанесения покрытий // Сборник научных трудов Национального аэрокосмического университета «ХАИ»: Сборник научных. - Харьков: НАУ «ХАИ», 2000. - № 21(4). - С. 55-66.

6. А.с. 1747728 СССР, ХНИИТМ F 02 F 3/14. Поршень из алюминиевого сплава для двигателя внутреннего сгорания / В.М. Темкин, Б.А. Подольский, В.Н. Власенко, Т.П. Гайдамака, А.Н. Косовцев, Э.С. Кулик (СССР). № 943423; заявл. 12.09.88; опубл. 15.07.92, Бюл. № 26.

\section{References}

1. Budenniy, M.M., Vlasenko, V.I., Movshovich, A.Ya. 2001. Povyshenie resursa i nadezhnosti detalej mashin metodom detonaczionno-gazovogo napyleniya uprochnyayushhikh pokrytij. Vestnik naczionalnogo tekhnicheskogo universiteta «KhPI», no. 11, pp. 94-98.

2. Popov, S., Gnitko, S., Vasyliev, A. 2020. Improving the abrasive resistance of a slide frame in a mortar mixer. Eastern-European Journal of Enterprise Technologies, no. 1/1(103), pp. 6-14.

3. Popov, S.V. 2008. Viznachennya kharakteristiki gazopolumenevogo napilennya na osnovi bagatofaktornogo eksperimentu. Mashinoznavstvo, no. 10, pp. 45-47.

4. Etingant, A.A., Storozhenko, V.S., Kolyadinskij, A.V. 1986. Osobennosti vakuumno-plazmennogo uprochneniya rezhushhego instrumenta iz bystrorezhushhej stali. Peredovoj opyt, no. 12, pp. 27-30.

5. Boguslaev, A.V. 2000. Issledovanie kachestva materiala detalej posle naneseniya pokrytij. Sbornik nauchnykh trudov Naczionalnogo aerokosmicheskogo universiteta «KhAl», no. 21(4), pp. 55-66.

6. Avtorskoe svidetelstvo 1747728 SSSR. 1992. Porshen iz alyuminievogo splava dlya dvigatelya vnutrennego sgoraniya.

\section{Detonation-gas Hardening of Parts of Internal Combustion Engines}

The paper deals with improving the reliability and durability of parts of the cylinder-piston group of internal combustion engines. Strengthening of machine parts is possible through the use of special production processes. Modern materials and coatings must be able to meet high operating temperatures and loads.

Chrome plating, boriding and ion-plasma spraying do not meet the established quality requirements. The aluminum piston suffers damage in the head area. This manifests itself in the accumulation of cracks, channels, and traces of alloy washout. In addition, due to heating, the strength of the aluminum alloy becomes worse more than 2 times.

It is proposed to create and use a coating that would withstand operating temperatures of more than $2000^{\circ} \mathrm{C}$, as well as shock-pulsating loads. A detonationgas spraying method is proposed. It is characterized by the versatility of materials and can be applied to polymers and to refractory ceramics, as well as to any metals and alloys.

The deposited particles have high kinetic energy. The coating is characterized by high strength, which reaches $180 \ldots 200 \mathrm{MPa}$, hardness HRCe 60, and minimal cracks. The temperature effect during spraying on the workpiece is negligible. A sequence of preparatory operations is proposed. The piston and glow ring on the 
UN-102 detonation-gas installation were to be strengthened. A manipulator was used that uses the energy of the installation shot.

The resulting surfaces are characterized by a regular macrostructure (waviness). A nickel-aluminum alloy was applied. Coating thickness was about $150 \ldots$ 270 microns, hardness was of HV 550, adhesion to the base eas of $94 \ldots 100 \mathrm{MPa}$. The results of studies on the parts of the cylinder-piston group showed a decrease in operating temperatures due to the running-in of the coating and high-quality sealing of the combustion chamber.

The durability of the rings is $1.6 \cdot 10^{6} \ldots 2.3 \cdot 10^{6}$, which indicates a significant increase in fatigue resistance and service life. The proposed technology is suitable and recommended for implementation in mass production. coating.

Key words: detonation-impulse hardening, piston, glow ring, spraying,

\section{Сведения об авторах:}

Фролов Евгений Андреевич - доктор технических наук, профессор, кафедра строительных машин и оборудования, Национальный университет «Полтавская политехника имени Юрия Кондратюка», г. Полтава, Украина; e-mail: frolov.poltntu@gmail.com; ORCID:0000-0002-2691-5386.

Попов Станислав Вячеславович - кандидат технических наук, доцент, кафедра отраслевого машиностроения, Полтавский государственный аграрный университет, г. Полтава, Украина; e-mail: psv26@i.ua; ORCID: 0000-0003-2381$152 X$.

Ясько Станислав Георгиевич - ст. преподаватель кафедры обработки материалов давлением ГВУЗ «Приазовский государственный технический университет», г. Мариуполь, Украина; e-mail: s.g.yasko@gmail.com; ORCID:00000001-6228-705X.

Орисенко Александр Викторович - кандидат технических наук, доцент, в.о. заведующего кафедрой строительных машин и оборудования, Национальный университет «Полтавская политехника имени Юрия Кондратюка», г. Полтава, Украина; e-mail: oleksandr.orysenko@gmail.com.

\section{About the Authors:}

Frolov Evgeniy Andreevych, Doctor of Technical Sciences, Professor, National University "Yuri Kondratyuk Poltava Polytechnic», Poltava, Ukraine; e-mail: frolov.poltntu@gmail.com; ORCID:0000-0002-2691-5386.

Popov Stanislav Vyacheslavovich, Philosophy Doctor, Associate Professor, Poltava State Agrarian University, Poltava, Ukraine; e-mail: e-mail: psv26@i.ua; ORCID: 0000-0003-2381-152X.

Yasko Stanislav Georhyevych - Senior Lecturer, State Higher Educational Institution "Priazovsky State Technical University", Mariupol, Ukraine; e-mail: s.g.yasko@gmail.com; ORCID: 0000-0001-6228-705X.

Oleksandr Orysenko Viktorovych - Philosophy Doctor, Associate Professor, Associate Professor, National University "Yuri Kondratyuk Poltava Polytechnic», Poltava, Ukraine; e-mail: oleksandr.orysenko@gmail.com; ORCID: 0000-0003-31030096. 